\title{
ARTIKEL
}

\section{Ethiek en recht, actio in distans}

\section{Special issue on Education in (Professional) Legal Ethics, Emanuel van Dongen \& Jet Tigchelaar (eds.)}

\author{
Marcel Becker*
}

\section{Abstract}

Deze text belicht achtergronden van het ethiekonderwijs aan juristen, zoals dat aan de Radboud Universiteit vorm krijgt. Centraal staat eerst de praktisch én theoretisch relevante spanning tussen ethiek en recht. Na een verkenning van deze spanning bespreekt Marcel Becker de status van ethische theorieën en de meerwaarde van sociaalwetenschappelijke kennis voor ethiekonderwijs.

Keywords: ethiekrecht, juridische beroepspraktijk, juridische opleiding.

\section{Inleiding}

In de roman Een klein leven vertelt een van de hoofdpersonen dat hij tijdens zijn juridische opleiding een vraag stelde over een netelig ethisch probleem in de beroepspraktijk. De docent schreef zwijgend iets op een papiertje en gaf dat aan de student, waarna hij zijn les vervolgde. Op het papiertje bleek het adres van de filosofische faculteit te staan. De hoofdpersoon van de roman (die in allerlei opzichten de sympathie van de lezer wint) ontwikkelt zich tot een genadeloos bedrijfsjurist (Yanagihara, 2017, p. 181). ${ }^{1}$ Voor u ligt een pleidooi voor een stevige poot ethiek in de juridische opleiding, maar enig begrip voor de docent heb ik zeker. Ethiek en recht gaan niet vanzelfsprekend samen.

Een eerlijke erkenning van de spanning tussen ethiek en recht is belangrijk, omdat de behoefte aan reflectie op de ethische dimensie van het werk structureel is. Niet alleen in het juridisch veld zien we een groeiende belangstelling voor beroepsethiek. Voor ambtenaren, bestuurders en managers zijn afgelopen jaren in zowel opleidingen als in organisaties uitgebreide trajecten van ethische reflectie opgezet. De belangstelling voor ethiek wortelt in brede maatschappelijke ontwikkelingen. Secularisering, globalisering en digitalisering zetten gangbare waardenen normenkaders onder druk en roepen nieuwe vragen op.

* Dr. Marcel Becker is associate professor Ethics and Political Philosophy, Radboud Universiteit, Nijmegen.

1 Vergelijk ook Hall, 1990, p. 541, die de citeert: 'If you want to study justice you should have gone to divinity school'. 
Inzake de verhouding tussen ethiek en recht is op verschillende niveaus te differentiëren. Er is de brede vraag welke rol ethische overwegingen kunnen spelen wanneer juridische overwegingen zijn uitgeput. Kan ethiek het recht aanvullen? Deze vraag komt hier slechts zijdelings ter sprake. Ik richt mij hier op de beroepsethische vragen naar goed handelen. Hoewel enkele algemene patronen zichtbaar zijn, spelen in elke beroepsgroep andere thema's. De ethische uitdagingen binnen de rechtspraak, advocatuur en het Openbaar Ministerie verschillen daarbij sterk, en ook de routes. Binnen het juridisch veld is daarbij nog sterk te differentiëren tussen de verschillende domeinen. De ethische uitdagingen binnen de rechtspraak, advocatuur en het Openbaar Ministerie verschillen sterk, ook de routes om tot ethische oordeelsvorming te komen zijn anders. Een gemeenschappelijk thema in alle deelgebieden is het principiële verschil tussen ethische en juridische reflectie. Het verschil sluimert vaak onderhuids maar steekt bij discussies plots ongemakkelijk de kop op. Ik open dan ook met een bespreking van dit verschil. Van hieruit kom ik tot belangrijke verschillen in motivatie om aan ethiek te doen. Vervolgens bespreek ik de relevantie én de beperkingen van theorieën. De beperkingen hebben te maken met de kloof tussen theorie en praktijk, die voor een ethiekopleiding een serieuze uitdaging vormt. Na suggesties gegeven te hebben voor hoe deze kloof te overbruggen, eindig ik met een bespreking van de vraag in hoeverre een opleiding ook echt vormend kan zijn.

\section{De relatie tussen recht en ethiek}

Er bestaan vele opvattingen over wat recht is, en vele opvattingen over wat ethiek behelst. Over één ding bestaat geen onenigheid: recht en ethiek behoren tot de kleine familie van normatieve wetenschappen: op enige afstand van de feitelijke gebeurtenissen formuleren ze maatstaven om het handelen van mensen te beoordelen. Ze onderscheiden zich hiermee van de andere grote wetenschapsgebieden, die zich primair richten op het ('objectief', 'neutraal') in kaart brengen van de werkelijkheid.

Ethiek en recht schuren echter met regelmaat ongemakkelijk langs elkaar. Juist tussen mensen en systemen die veel gemeenschappelijk hebben kunnen de heftigste conflicten ontstaan, zo zien we in familieruzies. Toch is het in beginsel vrij eenvoudig de disciplines van elkaar af te bakenen. Ze beroepen zich bij het formuleren van de normen op verschillende grondslagen. In het recht liggen de normen vervat in wetten die de (al of niet democratisch gelegitimeerde) wetgever uitvaardigt. Deze ontwikkelt een uitgebreid stelsel van vastliggende regels en voorschriften, die worden gedragen en uitgevoerd door zijn autoriteit en die van de legale instituties. Binnen het stelsel van regels bestaat een duidelijke hiërarchie. Ethiek op haar beurt is onderdeel van de wijsbegeerte, een duizenden jaren oude traditie van diepzinnige reflectie over de grote vraagstukken van het leven. De normatieve dimensie is daarin onlosmakelijk verbonden met antropologische, metafysische en kentheoretische vragen. Antropologische vragen, omdat gefundeerde uitspraken over goed en kwaad worden gedaan op basis van een bepaald mensbeeld, bijvoorbeeld inzake de relatie tussen emoties en ratio. Metafysische vragen omdat dergelijke uitspraken niet mogelijk zijn zonder een idee over de status van 
waarden: zijn deze puur menselijke verzinsels of zijn ze gegrond in een boven de mensen staande instantie? Een gedegen morele uitspraak impliceert ook kentheoretische overwegingen. Kunnen we neutraal feiten beoordelen, of spelen er altijd vooroordelen mee? ${ }^{2}$

Ethiek en recht verschillen niet alleen in de helderheid en eenduidigheid waarmee de normen vastliggen, ze leggen ook andere accenten in normativiteit. De wet drukt normativiteit uit in algemeen geldige regels, waarvan naleving afdwingbaar is. Dat brengt beperkingen met zich; sommige normatief gevoelige zaken zijn niet of zeer geforceerd in wetten uit te drukken. Wanneer dit niet lukt, is ethiek doorgaans nog wel in staat de normativiteit te verwoorden. Ik adstrueer dit met een extreem (maar wel verhelderend) en een minder extreem voorbeeld.

Folteren is volgens alle bestaande wetten en verdragen verboden. In de Verenigde Staten zijn het begin van deze eeuw pogingen gedaan om met behulp van zogenaamde torture warrants folteren in een legitieme vorm te laten plaatsvinden. Het is op een jammerlijke (juridische) mislukking uitgelopen. Een goede verklaring hiervoor is dat wat in foltering gebeurt, op geen enkele manier valt te rijmen met hoe een juridische autoriteit met mensen omgaat. De kwetsbare en weerloze persoon wordt naar willekeur behandeld, en dit is anders dan bij de meeste vormen van straf. Weliswaar bestaan er strafrechtvaardigingen waarin wraak centraal staat, maar doorgaans draagt straf een rationaliteit in zich, waarin de verdachte op zijn menselijke vermogens wordt aangesproken en bepaalde rechten heeft. Een straf wil de mens niet breken; veelal beoogt ze de gestrafte te verbeteren. In foltering daarentegen, wordt het slachtoffer tegen zichzelf opgezet door gebruik te maken van zijn pijnervaringen. Enerzijds ervaart de persoon pijn niet als deel van zichzelf. Hij heeft er niet voor gekozen, ze overvalt hem. Anderzijds is pijn als intense ervaring iets van de persoon zelf. Van die dubbelheid maakt de martelende persoon optimaal gebruik. Hij laat via de pijn zijn wil doorklinken, waarbij de gemartelde persoon tegelijkertijd machteloos én actief medeplichtig is. Zijn lichaam is zijn vijand; hij draagt actief bij aan zijn eigen vernedering. Waldron beschrijft het folterverbod als 'archetype' van wet: de wet is niet willekeurig, niet werkend op angst, en gebaseerd op respect voor waardigheid (Waldron, 2004). Het legaliseren ervan is te vergelijken met het legaliseren van meineed. De staat handelt dan jegens individuen met methodes die hij zelf veroordeelt.

De juridische redenering neemt niet weg dat in sommige situaties folteren vanuit morele motieven te verdedigen is. Bekend is het voorbeeld van de Duitse politiecommissaris Wolfgang Daschner, die in 2002 de ontvoerder van een kwetsbaar jongetje dreigde met foltering. Het Duitse Openbaar Ministerie kon niets anders doen dan de commissaris juridisch vervolgen. In de discussie hierover verdedigde de commissaris zijn optreden op morele gronden, en hij wist de publieke opinie voor een groot deel achter zich. Een ethische acceptatie van folteren heeft een lange traditie, die al begint bij de utilist Bentham, en tegenwoordig in Allhoff (2012) een vertegenwoordiger heeft.

2 De verwevenheid van ethiek met andere wijsgerige disciplines is niet onomstreden. Binnen de zogenaamde continentale wijsbegeerte krijgt zij een sterker accent dan binnen de analytische wijsbegeerte. 
Een iets minder extreem voorbeeld van het verschil tussen recht en ethiek komt uit de sfeer van integriteitsborging. Naar aanleiding van misstanden bij het Openbaar Ministerie verscheen voorjaar 2019 een rapport waarin ook de organisatiecultuur ter sprake kwam. Het rapport stelde dat wetgeving niet altijd de meest aangewezen weg is om te realiseren dat de grondbeginselen van integriteit kenbaar en helder zijn. De ethische kaders voor het werken bij de overheid lenen zich naar hun aard meer voor uitwerking in gedragscodes, richtlijnen en andere ethische instrumentaria (Fokkens, 2019, p. 38).

Wanneer de jurist de beperkingen van het recht niet erkent, dan is er sprake van legalisme, door Skhlar omschreven als 'the attitude that holds moral conduct to be a matter of rule following, and moral relationships to consist of duties and rights determined by rules' (Skhlar, 1964, p. 42). De legalist eigent zich het domein van de moraal toe in juridische termen, en miskent dat vanwege beperkingen van rechtsregels ethische reflectie noodzakelijk is. Volgens Skhlar schuilt in iedere jurist een legalist. Dat is wat sterk uitgedrukt, maar het is zeker dat een cursus ethiek voor juristen enkele legalistische tendensen moet overwinnen. Hiermee is niet gezegd dat juristen het bestaan van ethische overwegingen ontkennen. De rechtspositivist Hart heeft het belang van ethische overwegingen uitgebreid gethematiseerd (Hart, 1961, chapt. IX), maar geeft nadrukkelijk aan dat deze overwegingen binnen een juridisch stelsel geen plaats mogen hebben.

De grens tussen recht en ethiek staat weinig ter discussie in een stabiele maatschappij, waarin de wetgever de vaste samenlevingspatronen in vaste banen leidt. Ze komt onder spanning te staan in een dynamische samenleving, waar sterker de vraag speelt wat nog binnen het bereik van vaste regels kan vallen. In zo een samenleving zien we een zoektocht naar meer flexibiliteit in het rechtssysteem, waar open normen en mediation belangrijker worden. De rechtspraak gaat ook meer interfereren met andere geschilbeslechtende instanties: 'De rechter is zo een onderdeel van een breder rechtsvormend netwerk geworden dat is geworteld in de (inter)nationale samenleving en waarin toetsing vanwege de complexiteit van de regels door bijzondere toezichthouders en/of insiders geschiedt' (Buruma, 2016, pp. 46-47).

De ruimte die ontstaat zal ook met ethische reflectie gevuld worden. Het is zelfs denkbaar dat ethiek een plaats in de gereedschapskist van de jurist krijgt. Waar juridische regels tekortschieten, biedt ethiek nog ondersteuning. Niet alleen bij het komen tot normatieve uitspraken, maar ook bij het verantwoorden daarvan.

\subsection{Intrinsieke waarde en het vertrouwen van de samenleving}

Het onderscheid tussen ethiek en recht raakt ook de motivatie om zich met de disciplines bezig te houden. De juridische student is ermee vertrouwd (zeker als hij de advocatuur ingaat) dat hij zijn kennis instrumenteel inzet. Natuurlijk krijgt hij de centrale waarden van de rechtsstaat mee, maar daarbinnen zijn er de belangenen partijconflicten die met het juridisch instrumentarium worden 'uitgevochten'. In de ethiek daarentegen, gaat het om waarden die een intrinsieke kracht hebben. Met name deontologie en deugdethiek hebben uitgewerkt dat menselijk handelen uiteindelijk is gericht op zaken die, als hoogste goed, in zichzelf zinvol zijn. 
Dit verschil werkt door in de omgang met de vele documenten waarin de juridische professie haar gedragsnormen heeft vastgelegd. De Advocatenwet bevat de kernwaarden en advocaten hebben een uitgebreid tuchtrecht. Ook voor rechters heeft de wetgever regelingen vastgelegd. Daarnaast kennen alle juridische beroepsgroepen omvangrijke codes. Gevraagd naar het waarom van al deze inspanningen zal menig jurist erop wijzen dat hij afhankelijk is van het vertrouwen van de samenleving. Daar is veel voor te zeggen. Vanwege hun surplus aan kennis en bevoegdheden hebben juridische professionals macht over mensen. Ze spreken een taal die de leek niet beheerst en ze hebben privileges. De samenleving moet ervan op aan kunnen dat die macht niet verkeerd wordt gebruikt. Zij is afgelopen decennia alleen maar kritischer geworden. De macht en het gezag van de professional zijn niet meer vanzelfsprekend; de professional moet ze verdienen. Beroepsethiek speelt hierin een rol.

De legitimatie tegenover de samenleving zou wel eens een heel sterke motivatie voor beroepsethiek kunnen zijn. Afgelopen jaren is het aantal ethische misstanden niet alarmerend gegroeid. Daarin ligt dus geen reden voor de opkomende aandacht voor beroepsethiek. Het doet het vermoeden rijzen dat de aandacht vooral is ingegeven door het verlangen van de juridische professionals om hun positie veilig te stellen. 'Beroepsethiek lijkt (...) vooral ook een instrument in handen van professies en professionals die hun autonomie en soms ook hun monopoliepositie trachten te verdedigen', zegt Mackor in haar preadvies voor de Nederlandse Juristen-Vereniging (NVJ) (Mackor, 2020). Haar formulering is wel heel strategisch: ze suggereert een ethische bekommernis in dienst van het belang van de beroepsgroep. Strategisch of niet, feit is dat de overweging 'wat zouden de mensen ervan denken' zichtbaar is in de wijze waarop verschillende juridische professies over ethiek spreken. De notie 'justice must not only be done, it also must be seen to be done' is een gevleugelde spreuk onder rechters; zij is meerdere keren door het Europese Hof voor de Rechten van de Mens gebezigd (Dijkstra, 2017, p. 11 geeft enkele referenties). Eenzelfde ambitie spreekt uit de gedragscode van het Openbaar Ministerie 'zichtbaar op te treden' en 'omgevingsgericht' te zijn. De gedragsregels van de advocatuur stellen eerst dat de advocatuur 'een door ethiek gekenmerkt' beroep is, maar dat 'disciplinerende gedragsregels instrumenteel en noodzakelijk zijn' (NOvA, 2018). U kunt ervan uitgaan dat in bijvoorbeeld gesprekken tussen de deken en advocaat over morele dilemma's menigmaal het oog van de buitenwereld ter sprake komt.

Deze gerichtheid op de buitenwereld wekt bij de filosoof meteen een verdenking. Wanneer de motivatie tot goed handelen vooral door de buitenwereld wordt ingegeven, handel je dan minder goed als je ervan overtuigd bent dat de buitenwereld het niet te weten komt? Die vraag is zo oud als de wijsgerige ethiek; Plato introduceerde in de Politeia al het gedachte-experiment van 'de ring van Gyges', die een mens onzichtbaar maakt. Als je deze ring draagt, handel je dan hetzelfde als wanneer je voor ieder zichtbaar bent?

Zo komen we tot de paradox dat de juridische wereld neigt tot een instrumentele (strategische) inzet van ethiek, die vanuit haar eigen aard tot intrinsieke waarden neigt. Deze formulering is geen vrijblijvend gedachtespel. We zien de paradox direct terug in ethische dilemma's die binnen de beroepsgroep spelen. Wat als 
de buitenwereld vraagt om bepaalde maatregelen, waarvan de professional weet dat die op termijn niet goed uitpakken? Het Openbaar Ministerie kan ervan overtuigd zijn dat criminaliteitsbestrijding gebaat is bij een beleid waarin niet de meest in het oog springende zaken met urgentie worden vervolgd. Een rechter kan een uitnodiging voor een informele bijeenkomst afslaan om alle schijn van partijdigheid te vermijden, terwijl op die bijeenkomst nuttige informatie valt te halen. Het oog van de buitenwereld is een belangrijke factor, maar kan strijden met de kerntaken en waarden van de beroepsgroep.

Voor de juridische beroepsgroepen ligt de sleutel tot een goede omgang met deze paradox in communicatie. In bijna alle geledingen van het juridische veld zijn omvangrijke communicatietrajecten uitgezet om de samenleving ervan te overtuigen dat hetgeen juristen vanuit hun intrinsieke motivatie doen het beste is voor de samenleving.

\subsection{Het onderscheid tussen ethiek en recht in het onderwijs}

De theoretische bagage die we de student meegeven is ontwikkeld tegen de achtergrond van metafysische, anthropologische en kentheoretische denkbeelden. Haar toepassing op moderne (beroepsethische) vraagstukken vereist dat die achtergrond wordt meegenomen. De 'toegepaste ethiek' (waarvan beroepsethiek een onderdeel is) wordt wel eens geopponeerd aan 'fundamentele' ethiek. Het zou gaan om andere takken van sport: de studie van de grote wijsgeren versus de inzet van hun denkbeelden in actuele kwesties. Dat onderscheid is problematisch. Toegepaste ethiek laat de klassieke werken van wijsgeren niet achter zich, maar verbindt deze met hedendaagse problemen. Professionele ethiek is niet een van de fundamentele ethiek losgezongen discipline, ze wortelt erin.

Als de wijsgerige dimensie van normatieve uitspraken niet op een of andere manier wordt meegenomen, dreigen er twee gevaren: relativisme en moralisme. In het eerste extreem ziet men niet hoe normatieve uitspraken zijn geworteld in meer omvattende gedachtestelsels, en dan zijn ze al snel willekeurig. Ethiek is dan een vrijblijvend gedachtespel over normatieve posities. De (ook onder juristen regelmatig te beluisteren) constatering dat ethiek weinig normatieve kracht, heeft zou wel eens te maken kunnen hebben met onbekendheid met deze dimensie. In de verduidelijking ervan ligt een schone taak voor de ethici. In het tweede extreem, moralisme, gaan de subtiliteit en diepzinnigheid van de wijsgerige onderbouw verloren. Zo zien we in pleidooien voor meer ethiek in de opleiding wel eens de neiging om ethiek op te vatten als het direct overbrengen van een welbepaalde boodschap aan de studenten. Ethiek moet dan de eenzijdige juridische oriëntatie corrigeren, door te wijzen op de vereiste medemenselijkheid van de jurist. Dergelijke eenduidige boodschappen kunnen hun functie hebben. Charismatische docenten die uitdragen dat je als jurist de menselijke maat nooit uit het oog mag verliezen, blijven studenten hun leven lang bij. Het nadeel van een dergelijke inzet is dat ze al snel ontaardt in moraliseren: luidop iets articuleren waarvan ieder eigenlijk wel weet dat het moet - al houdt lang niet ieder zich eraan.

De ethiekopleiding staat daarmee voor de uitdaging om de student gevoeligheid voor de ethische dimensie bij te brengen, maar deze niet te laten uitlopen in het vertellen van algemeen als correct bevonden boodschappen. Die gevoeligheid 
kan inderdaad op meerdere manieren worden bijgebracht. Zo kan op academisch verdiepende manier de achtergrond van goed en slecht handelen worden belicht. De ethische theorie van de deugdethiek, die inzet op morele vorming, is hiervoor geschikt (zie bijvoorbeeld Annas, 2013). Ook sociaalwetenschappelijke kennis - waarover later meer - is hiervoor in te zetten. En natuurlijk geldt voor ethiek als onderdeel van de wijsbegeerte: niet moraliseren, maar problematiseren. Zij traint de student om kritische, normatieve vragen te stellen. In het ondergraven van de vanzelfsprekendheden komt het tot een verdieping die het mogelijk maakt de morele dimensie op een verantwoorde manier te vertalen naar de weerbarstige praktijk. Over de rol van de ethische theorieën bij deze verdieping kom ik later te spreken.

De noodzaak van wijsgerige bezinning is breder dan het domein van ethische theorieën. Voor ieder maatschappelijk systeem geldt dat reflectie over het systeem niet kan plaatsvinden in termen van dat systeem zelf. Een analyse van de eigen aard, de kwaliteit, de relevantie en de noodzaak van fundamentele begrippen als '(mensen)recht', 'wet', 'waarheidsvinding' en 'procedure' vraagt om een benadering waarin we buiten het juridisch systeem stappen. Dat brengt ons bij de klassieke wijsgerige vragen. Toegepast op beroepsethiek betekent deze gedachtegang het volgende. Iedere jurist komt vroeg of laat voor de vraag te staan waar het gedragsrecht goed voor is, hoe hij de (gedrags)regels invulling geeft, en misschien zelfs of hij zich er wel aan moet houden. Een juridisch antwoord op deze vragen volstaat niet, omdat over die antwoorden dan weer dezelfde vragen gesteld kunnen worden. Vroeg of laat dringt zich in de omgang met juridische regels dus buiten-juridische reflectie op. Op dit punt springt ethische reflectie in. Dit lijkt me de diepere betekenis te zijn van de preambule van de advocatuurlijk gedragsregels, die stelt dat de regels 'zijn bedoeld als richtlijn voor de advocaat voor zijn handelen bij de uitoefening van de praktijk' (NOvA, 2018). De gedragsregels leggen een niet in strikt juridische termen te verwoorden basis voor het gedragsrecht.

Vanuit het belang van reflectie over het juridisch systeem is het binnen de Nijmeegse rechtenopleiding al decennialang goed gebruik om de eerstejaarsstudenten een verplicht vak rechtsfilosofie aan te bieden. Het bestaat uit een serie hoorcolleges en een aantal werkgroepronden, waarin klassieke wijsgerige teksten centraal staan, niet in het bijzonder teksten van grote ethici. Centraal staan veeleer (mensen)rechten en grondslagen van de rechtsstaat. De toetsing geschiedt aan de hand van open vragen. Voor deze tentaminering is gekozen, omdat in wijsbegeerte bij uitstek de formulering alles zegt over de beheersing van de inhoud. Op deze wijsgerige basis bouwen de beroepsethische vakken voort die de jaren erna aan bod komen.

\section{De status van ethische theorie}

Beroepsethiek handelt over de normatieve dimensie van de handelingen die de professional verricht. Die dimensie is niet een 'gegeven', waarvan het bestaan objectief kan worden aangetoond. Empirische wetenschappen laten wel zien dat mensen ethisch goed of slecht handelen. Zij kunnen niet aantonen wat de eigen aard van dat goede en slechte is. Het waarschijnlijk meest gebruikte middel om de 
juridische student de normatieve kaders van ethiek mee te geven is de ethische theorie. In het bijzonder deugdethiek, deontologie en utilisme spelen een rol in ieder beroepsethisch curriculum. Wat is precies de status van deze theorieën? Waartoe zijn ze wel en niet in staat? Ze geven als normatieve theorieën richting aan het handelen. Hierin zijn verschillen ze. Deontologie en utilisme beogen handelingsvoorschriften. Dat klinkt goed voor de mensen die van ethiek direct toepasbare antwoorden verwachten, maar niet te vroeg gejuicht. Hoewel ze beide in dezelfde tijd (de Verlichting) zijn ontstaan, komen ze tot verschillende, soms zelfs tegengestelde uitkomsten. Blijkbaar is de verlichtingsrationaliteit niet zo eenduidig. De deugdethiek is veel minder prescriptief maar kan beter uit de voeten met morele emoties, die ze cultiveert en aldus een plaats geeft.

De drie theorieën staan in het Nijmeegs curriculum centraal in de cursus 'Ethiek voor juristen'. Maar de cursus erkent ook hun beperkingen. De verschillen tussen de theorieën roepen twijfels op over de exclusiviteit van hun normatieve pretentie. Het gevaar bestaat dat men naïef met die twijfel omgaat. Men behandelt dan de theorieën vanuit de suggestie dat er groepen deugdethici, deontologen of utilisten bestaan, die ieder eenzijdig vanuit een mens- en wereldbeeld de normatieve dimensie benaderen. Van hieruit is het dan een kleine stap van de student te vragen zich tot een van de drie theorieën te bekennen. Zo een beweging is een vreemde overschatting van de theorieën. Ik ben nog nooit een zuivere utilist, deontoloog of deugdethicus tegengekomen. Eerder dan de theorieën te zien als zelfstandige entiteiten waaraan mensen zich zouden overgeven, ligt het voor de hand te erkennen dat geen enkel theoretisch bouwwerk de (normatieve) waarheid in pacht heeft. Ook als prescriptieve theorieën doen ze niet méér dan kernelementen van onze moraliteit verwoorden. Ze verhelderen morele ervaringen. De theorieën maken duidelijk hoe morele reflexen en emoties zijn te begrijpen vanuit overwegingen die voor goed samenleven onmisbaar zijn. De deontologie wijst op absoluut geldende plichten als basisvoorwaarden voor het samenleven en een geordend beroepsleven, het utilisme is de theorie van de bestuurder die moeilijke afwegingen maakt, en de deugdethiek geeft met haar rijke morele psychologie het aspiratieve karakter van moraal aan. Eerder dan studenten zich te laten bekennen tot een van deze drie, lijkt me het de uitdaging studenten er vertrouwd mee te maken hoezeer de theorieen een aspect van de morele gevoeligheid verwoorden (zie voor de rechtspraak Kwak, 2005). In de toepassing vraagt menigmaal de aard van de casus zelf om inzet van een bepaalde theorie.

Die verheldering geldt nadrukkelijk ook voor morele sleutelconcepten als integriteit, verantwoordelijkheid en respect. Zij hebben verschillende betekenissen, die we doorgaans met grote vanzelfsprekendheid gebruiken. Maar het maakt nogal wat uit of iemand het begrip 'respect' vanuit een (kantiaanse) 'autonomie' achtergrond gebruikt, of vanuit een deugdethische manier, waarin inlevingsvermogen en interactie centraal staan.

De theorieën zijn ook menigmaal complementair. $\mathrm{Zo}_{\mathrm{o}}$ is voor integriteitstrajecten binnen organisaties in eerste instantie de deontologie maatgevend geweest. Integriteit bestond uit het naleven van (dikwijls in een code) vastgelegde kaders. Na verloop van tijd kwam de deugdethiek op. Zij brengt de alledaagse mo- 
rele bekommernissen op de werkvoer beter ter sprake, en heeft oog voor morele ontwikkeling (Becker e.a., 2010).

Deze positionering van ethische theorieën geeft aan dat een ethiekcursus de student niet alleen een theoretische bagage meegeeft, maar ook een morele ontvankelijkheid, en het vermogen om gebeurtenissen en handelingen op een bepaalde manier te waarderen. Voordat ik dit uitwerk, bespreek ik eerst een andere theoretische invalshoek, die in cursussen ethiek een rol dient te spelen: het sociaalwetenschappelijke perspectief.

\section{Kennis vanuit de sociale wetenschappen}

Afgelopen decennia hebben sociale wetenschappen zwakheden in de menselijke psyche blootgelegd, die een doorslaggevende rol spelen in het al of niet goed handelen van mensen. Ieder kent het Milgram-experiment, waarin de menselijke gevoeligheid voor autoriteit is blootgelegd, en het Asch-experiment over menselijk conformisme. Door Nobelprijswinnaar economie Kahneman weten we dat mensen zich op het verkeerde been laten zetten door het 'eerste', impulsief reagerende denksysteem. Het is algemeen erkend dat implicit bias en cognitieve dissonantie leiden tot een slechte inschatting van situaties.

Dergelijke sociaalwetenschappelijke inzichten leveren materiaal voor een cursus ethiek, maar dat betekent niet dat onderdelen van de cursus tot het domein van de sociale wetenschappen behoren. Sociaalwetenschappelijke kennis verschilt principieel van ethiek als normatieve wetenschap. De sociale wetenschappen hebben een lange geschiedenis achter de rug, waarin ze zich hebben bevrijd van normatieve claims; het objectiviteitsstreven staat er hoog in het vaandel. Of ze dit waarmaken is natuurlijk de vraag - maar beantwoording daarvan hoort thuis in een cursus 'Ethiek voor sociaal wetenschappers'. In ieder geval is er een verschil tussen de normatieve inzet van de ethiek en de (pretentie van) methodologische neutraliteit van de sociaal wetenschapper; beoordelen is iets anders dan beschrijven. In een cursus ethiek moet daarom de sociaalwetenschappelijke kennis vanuit een wijsgerig en normatieve invalshoek worden benaderd. Dat klinkt zwaar, maar het is gemakkelijker gedaan dan gezegd. De sociaalwetenschappelijke bevindingen roepen vragen op over de vertaling naar de normatief geladen praktijk, waarmee de docent aan de slag kan gaan. Ik geef enkele voorbeelden.

- De experimenten van Stanley Milgram zijn klassiekers in colleges over factoren die mensen afleiden van goed gedrag. Het staat echter niet zo eenduidig vast wat de les is van deze experimenten. Op de YouTube-filmpjes is te zien dat de proefpersonen zich niet klakkeloos overgaven, maar weerstand toonden en zich zeer ongemakkelijk voelden. Toonden de experimenten aan dat karakter geen stevige basis van handelen is, of toonden ze aan dat mensen in extreme situaties na interne worsteling bereid zijn tot extreme daden? Bewijzen de experimenten dat mensen gevoelig zijn voor de uitstraling van personen die hoog in de hiërarchie staan, of zijn mensen gevoelig voor de autoriteit die iemand als deskundige uitstraalt? De Amerikaanse samenleving van de jaren zestig verschilt in veel opzichten van de hedendaagse samenleving. Is de kracht van autoriteit nog even sterk? 
- Met de beschrijving van eindeloos veel voorbeelden legt Kahneman uit dat in ons bewustzijn intuïtie en bewuste analyse om voorrang strijden. Hij beschrijft uitgebreid de kenmerken van beide systemen, merkt op dat ze meestal goed samenwerken (Kahneman, 2011) en toont vervolgens aan de hand van vele voorbeelden aan hoezeer ze verschillen, en dat ze kunnen botsen. De vraag naar kennis hoe mensen in elkaar zitten is echter een andere vraag dan die hoe met deze kennis om te gaan. Kahnemans boek Ons feilbare denken biedt enkele handvatten voor economen, en schetst enkele confronterende experimenten onder rechters. Het is echter aan juristen om hier zelf mee aan de slag gaan. De discussie binnen de rechterlijke macht over de relatie met de deskundigen (waaronder statistici) is hiervan een mooi voorbeeld. In ethiekcolleges kan de misleidende rol van intuïties worden geplaatst naast intuïties omtrent goed en kwaad, die een bron van moreel besef zijn. Ook is uit te werken dat de wijze waarop de denksystemen interfereren verschilt van persoon tot persoon. Een cursus ethiek leidt dan tot zelfkennis.

- Implicit bias en cognitieve dissonantie leiden ertoe dat het goedwillende indivi$\mathrm{du}$, zonder zich daarvan bewust te zijn, afwijkt van ethische standaarden. Hoe zijn deze mechanismen tegen te gaan? Zelfkennis is niet toereikend; het gaat immers juist over situaties waarin mensen zichzelf op het verkeerde been zetten. Het ligt dan voor de hand dat de organisatie in haar structuur en cultuur mechanismen inbouwt om mensen moreel scherp te houden. De discussie hoe ver ze hierin moet gaan roept wijsgerige vragen op (Perquin-Deelen, 2020). Bij hardnekkige problemen en ongelijkheden wordt positieve discriminatie gesuggereerd. Een minder extreme aanpak is via richtlijnen en protocollen, maar die doorkruisen al snel de autonomie van professionals. Zo wijzen Emmerik, Loof en Schuurmans erop, dat de zaakstoedeling (waar natuurlijk implicit bias en cognitieve dissonantie een negatieve rol kunnen spelen) niet bij wet is geregeld; het gerechtsbestuur zorgt daarvoor. Het gevolg is een ad-hocbeleid, met gebrek aan transparantie (Emmerik, Loof \& Schuurmans, 2014). Hoe wenselijk is het dat dit verandert?

Bij de behandeling van deze vragen wordt sociaalwetenschappelijke kennis ingezet vanuit een wijsgerig-normatieve perspectief. Hierbij zijn ethische theorieën behulpzaam. De deontologie zet op scherp dat begrijpen van gedrag iets anders is dan beoordelen van gedrag. Kant ontwierp zijn deontologische theorie in nadrukkelijk onderscheid van empirische kennis. De (kennis over de) stand van zaken in de wereld is niet van invloed op de ethische grondregels. Het utilisme wil juist sociaalwetenschappelijke kennis gebruiken. In de beperkingen van het utilisme komen ook de tekortkomingen van dit gebruik naar voren.

De deugdethiek gaat ervan uit dat (sociaalwetenschappelijke) vakkennis verschilt van, maar in de praktijk verstrengeld ligt in, morele kennis. Naast vakinhoudelijke kanten heeft iedere situatie een morele dimensie. Aristoteles' schets van het verschil tussen beide in boek VI van de Ethica (Aristoteles, 1999, pp. 1140a11140 b29) is behulpzaam bij het afbakenen ervan. De vakinhoudelijke kant is een zaak van experts; praktische wijsheid wordt van ieder mens gevraagd. De vakinhoudelijke kant is gericht op een bepaald segment, de vragen die praktische wijsheid behandelt hebben betrekking op wat het leven als geheel goed maakt. De vak- 
inhoudelijke kennis is gericht op het maken van een (im)materieel product; de praktische verstandigheid betreft het in het handelen vormgeven van het goede leven. Daarnaast biedt de deugdethiek een vocabulaire om menselijke karaktereigenschappen normatief te bespreken. Zo zijn vanuit de vier klassieke ('kardinale') deugden gewenste eigenschappen van professionals ter sprake te brengen. Er wordt moed gevraagd van mensen die zich willen verzetten tegen passiviteit en heersende vooroordelen. De matigheid kadert impulsieve reflexen in. Rechtvaardigheid beoogt een zakelijke beoordeling, gericht op de substantiële vraag, zodat ieder het zijne krijgt. Door alle deugden heen speelt morele verstandigheid.

\section{Morele gevoeligheid}

De jurist krijgt theoretische bagage mee, maar die heeft beperkingen. Ethische theorieën kunnen niet de kern van de ethische dimensie eenduidig verwoorden. De sociaalwetenschappelijke theorieën negeren de normatieve dimensie. Vanuit deze tekortkomingen van theorieën moeten we een uitspraak van Aristoteles serieus nemen, die vaak wat lacherig wordt aangehaald. Ethiekonderwijs is pas vruchtbaar voor mensen die ervaren zijn 'in de praktijk van het leven' (Aristoteles, 1999, p. 1095a2), waaraan hij toevoegt dat jongeren zich te veel laten meeslepen door emoties. Aristoteles had daarbij mensen (in zijn geval mannen) van middelbare leeftijd op het oog. Discussies over tijd- en cultuurgebonden leeftijds- en seksegrenzen leiden al te vaak af van de kern van Aristoteles' uitspraak. Ethiekonderwijs slaagt pas als het een beroep doet op morele gevoeligheid. Zonder een ontvankelijkheid bij de student heeft dat onderwijs geen zin.

Zeker is dit morele voorverstaan 'persoonlijk'. Ze is gevoed door eigen ervaringen en verschilt van individu tot individu. Inspelen op die persoonlijke ontvankelijkheid is geen vanzelfsprekendheid in de opleiding tot juridische professional. Het recht is een systeem dat de samenleving als geheel ordent, en daarin kan voor menselijke, al te menselijke motieven niet veel ruimte zijn. Die huiver is koudwatervrees; we kunnen beter de redenering omkeren. Gegeven het belang van ethiek is het een uitdaging om de menselijke factor goed vorm te geven. In die vorming ontstaat een vicieuze (beter: 'virtuele') cirkel tussen het morele voorverstaan en wat wordt overgedragen in het onderwijs. Het lijkt me dat deze dynamiek ten grondslag ligt aan de gangbare leerdoelformuleringen als 'bewustwording' en 'ontwikkelen van een professionele attitude'.

Tegen deze achtergrond heeft de Radboud Universiteit Nijmegen besloten het vak 'Ethiek voor juristen' als laatste vak in de bachelor aan te bieden, en verplicht te stellen voor alle studenten. Zij hebben dan al enige gevoel voor de praktijk ontwikkeld. De tentaminering vindt plaats met open vragen, die kennis en inzicht toetsen. In de tentameninstructie krijgen de studenten mee dat de docent de antwoorden beoordeelt vanuit de overweging dat zij in staat moeten zijn een ethische beslissing gedegen én helder te verantwoorden - dit gaat in filosofie niet altijd samen.

Omdat de bewustwording en de attitude zich ontwikkelen in de praktijk, verloopt onderwijs aan dagstudenten anders dan onderwijs voor professionals. De ethieksessies met praktijkmensen kennen een betrokkenheid en doorleefdheid die 
bij dagstudenten afwezig is. Hier blijkt, in de woorden van Martha Nussbaum, dat morele kennis groeit met het vermogen 'to make situations real inside oneself, to understand their human meaning' (Nussbaum, 1990). Ze vergelijkt dit vermogen met een menselijke spier, die getraind moet worden. De docent die daarop niet direct inspeelt mist een kans - en keert na de slechte evaluatie niet meer terug. Misschien is in dit verschil tussen dagstudenten en praktijkmensen de oorzaak dat ethische theorieën in dagonderwijs een relatief grote rol spelen. Waar niet direct op de levende ervaring ingespeeld kan worden, grijpen we naar theorie. Praktijkmensen daarentegen, hebben wel wat beters te doen dan zich er druk over te maken of ze utilist, deontoloog of deugdethicus zijn. Wel blijven de theorieën nuttig op de manier die ik hiervoor heb beschreven.

Met de opkomst van onderwijs in beroepsethiek is driftig gezocht naar manieren om de praktijkervaring de collegezaal binnen te brengen:

- Tijdens (snuffel)stages ervaren studenten ethische problemen, die ze in het onderwijs bespreken. Het roept de vraag op, op welke wijze je ethische reflectie op eigen ervaringen goed vorm kunt geven. Op dit punt zouden academische ethiekopleidingen wel eens in de leer kunnen gaan bij de advocatenopleiding. In een omvangrijk ethiektraject kent deze uiteenlopende vormen van reflectie op de doorleefde praktijk.

- Een gastcollege van iemand uit de praktijk. Het Nijmeegse vak 'Ethiek voor juristen' kent standaard een gastcollege. Dat kan iemand zijn die grote affiniteit heeft met de ethische dimensie van het werk, maar dat hoeft niet. Als gastdocent aan het Koninklijk Instituut voor de Marine in Den Helder heb ik een aantal lezingen gefaciliteerd, waarin hoge militairen met operationele ervaring vertelden welke ethische dilemma's ze tegenkwamen en hoe ze daarmee omgingen. In de discussie na de lezing integreerde ik hun verhaal in de theorie, maar in de lezingen zelf kwam al veel over de eigen aard van ethiek naar voren. Het praktijkverhaal kende weinig ethische reflectie, en van theorieën was al helemaal geen sprake. Maar het was méér dan anekdotiek. De (morele) motivatie van de militair sprak direct tot de adelborsten, en de morele standaarden kwamen tot leven. En niet als abstracte principes: hun volle betekenis kwam tot zijn recht in de concrete situaties. Het narratief was toegang tot morele kennis.

- Ook romans en fictieve verhalen zijn een manier om de levende praktijk in de collegezaal te brengen. Martha Nussbaum heeft uitgewerkt dat op law schools de 'narrative imagination' geprikkeld kan worden door narratieve teksten die, misschien nog meer dan de levende praktijk, de ambivalente, pijnlijke, tragische momenten schetsen op een manier die tot denken aanzet. (Nussbaum, 1990)

Wanneer in ethiekonderwijs het morele voorverstaan centraal staat, is de concrete context van belang. De morele gevoeligheid ontwikkelt zich immers in een bepaalde omgeving. Mensen die moreel goed optreden in de ene omgeving, laten in een andere steken vallen. Ethiekonderwijs moet die verscheidenheid onder ogen zien. Zij richt zich niet primair op het brede kader van 'de rechtsstaat' (de specifieke normatieve kanten daarvan komen wel aan bod in andere vakken), maar op de vraag hoe de rechtsstatelijke waarden doorwerken in de verschillende juridische 
velden. Een cursus beroepsethiek wint aan spanning en diepgang bij verheldering van de verschillen. Tegenover de onpartijdigheid en onafhankelijkheid van de rechter staan de partijdigheid (en niet-afhankelijkheid) van de advocaat. Naast de gevoeligheid voor de samenleving van het Openbaar Ministerie staat de wetgevingsjurist, die op zijn manier rekening houdt met wat er in de samenleving gebeurt. Professionele ethiek wordt pas levend wanneer deze concrete niveaus ter sprake komen.

De verscheidenheid wordt binnen de Nijmeegse rechtenopleiding ook recht gedaan doordat verschillende specialisaties modulen ethiek kennen. Zo bevat de notariaatsopleiding een vak notarieel recht. De masteropleiding Onderneming en Recht kent een aparte module ethiek.

\section{Tot slot}

Beroepsethisch onderwijs staat voor de uitdaging een vruchtbare dynamiek tot stand te brengen tussen reflectie, die leunt op duizenden jaren wijsbegeerte en de levende morele ervaring, die door de praktijk wordt gevoed. Ethische theorieën, kernwaarden en normen in codes, sociaalwetenschappelijke kennis, het staat allemaal in dienst hiervan. Deze dynamiek is niet aan specifieke onderwijsvormen gebonden. Natuurlijk klinkt het prachtig dat in werkgroepen een klassieke tekst wordt gelezen. Maar exegese zonder aandacht voor wat die tekst onze hedendaagse morele conditie te zeggen heeft, draagt slechts beperkt bij aan morele vorming. Een gastcollege is mooi, maar moet wel méér zijn dan anekdotiek plus wat moraliseren. Open vragen die louter op kennisreproduktie zijn gericht zijn minder geschikt dan multiplechoicevragen die om een juiste interpretatie van een moreel concept vragen. De gewenste dynamiek is in vele onderwijsvormen te ontwikkelen, in zowel het klassieke curriculum, als in programma's met aansprekende (maar ook tautologische) titels als 'law in society' en 'law in action' en 'law practice'.

\section{Literatuur}

Allhoff, F. (2012). Terrorism, ticking time-bombs and torture. Chicago: University of Chicago Press.

Annas, J. (2013). Intelligent virtue. Oxford: Oxford University Press.

Aristoteles (2019). Ethica Nicomachea. (Pannier, C., Verhaeghe, J., Bons, J. A. E., \& Ophuijsen, J. M., vert.). Groningen: Historische Uitgeverij.

Becker, M. e.a. (2010). Deugdethiek en integriteit. Assen: Van Gorcum.

Buruma, Y. (2015). De veranderende literaire verbeelding van het recht [Lezing]. Grotius Lustrumcongres 'Recht \& Taal', Nijmegen.

Buruma, Y. (2016). Wat is een goede rechter? Een mentaliteitsgeschiedenis (1900-2020) [Oratie]. Nijmegen: CPO - Radboud Universiteit.

Dijkstra, S. (2017). The freedom of the judge to express his personal opinions and convictions under the ECHR. Utrecht Law Review, 13(1), 1.

Emmerik, M. L., Schuurmans, Y., \& Loof, J.-P. (2014). Rechtspraak anno 2014: Vertrouwen is goed maar controle kan (nog) beter. NJB, 2228.

Fokkens, J. W. (2019). Rapport van de Onderzoekscommissie Openbaar Ministerie [Bijlage bij Kamerbrief]. Den Haag. 
Hall, T. (1990). Moral character, the practice of law and legal education. Mississippi Law Journal, 511-550.

Hart, H.L.H. (1961). The concept of law. Oxford: Clarendon Press.

Kahneman, D. (2016). Ons feilbare denken. Thinking, fast and slow. Amsterdam, Antwerpen: Business Contact.

Kwak, A.-J. (2005). The legal junction. The complex promise of modern legal professionalism. Alblasserdam: Haveka BV.

Mackor, A. R. (2020). 4 Juridische beroepsethiek; Over macht en moraal, soft law en soft skills, T-vormige juristen en kansen-rechters. In De toekomst van de jurist, de jurist van de toekomst (NJV 2020-1) 2020/4 (1ste dr., vol. 4, p. 208). Deventer: WoltersKluwer.

NOvA. (2018). Gedragsregels Advocatuur. Wet- en regelgeving van de NOvA. http:// regelgeving.advocatenorde.nl/content/gedragsregels-advocatuur.

Nussbaum, M. C. (2003). Cultivating humanity in legal education, University of Chicago Law Review, 70(1), Article 18.

Perquin-Deelen, Ch. (2020). Biases in de Boardroom en de Raadkamer. Een juridische en filosofische analyse van de bestuurlijke taakuitoefening en rechterlijke beoordeling, mede aan de hand van een empirische studie (Proefschrift. Serie vanwege het Van der Heijden Instituut, deel 160), Deventer: WoltersKluwer.

Shklar, J. N. (1986). Legalism: Law, morals, and political trials. Cambridge: Harvard University Press.

Waldron, J. (2004). Torture and positive law: Jurisprudence for the White House. UC Berkeley: Kadish Center for Morality, Law and Public Affairs. Retrieved from https:// escholarship.org/uc/item/23d27577.

Yanagihara, H., Ruitenberg, J., \& Pouwels, K. (2016). Een klein leven. Amsterdam: Nieuw Amsterdam. 